21. Рекомендація CM/Rec (2010) 12 Комітету Міністрів Ради Європи державам-членам щодо суддів: незалежність, ефективність та обов'язки. URL: http://zakon2.rada.gov.ua/laws/ show/994_a38

22. Бангалорські принципи поведінки суддів від 19 травня 2006 p. URL: http://zakon5.rada.gov.ua/laws/ show/995_j67

23. Висновок (2002) 3 Консультативної ради європейських суддів щодо принципів та правил, які регулюють професійну поведінку суддів, зокрема, питання етики, несумісної поведінки та безсторонності. URL: http://vkksu.gov.ua/userfiles/doc/perelik-dokumentiv/vys3.pdf

24. Про судоустрій і статус суддів: Закон України в редакції від 7 липня 2010 р. (втратив чинність). URL: http://zakon3.rada.gov.ua/laws/show/2453-17

25. Про Вищу раду юстиції: Закон України в редакції від 15.01 .1998 р. (втратив чинність). URL: http://zakon3.rada.gov.ua/laws/show/22/98-\%D0\%B2\%D1\%80

26. Рішення ЄСПЛ у справі «Олександр Волков проти України» (Заява № 21722/11, 9.01.2013 p., остаточне 27.05.2013 p.). URL: http://www.scourt.gov.ua/clients/vsu/vsu.nsf/(documents)/895EB1EFA4312A8DC22580F8003DFA2D

DOI 10.31558/2518-7953.2019.2.6

УДК 343.9

$\boldsymbol{I} . \boldsymbol{A . ~ Ц е р б а к , ~}$
доцент кафедри конституційного,
міжнародного і кримінального права
Донецького національного університету
імені Василя Стуса,
кандидат юридичних наук, доцент
$\boldsymbol{C}$ О. Патюк,
доцент кафедри конституційного,
міжнародного і кримінального права
Донецького національного університету
імені Василя Стуса,
кандидат юридичних наук

\title{
ЩОДО ПРОЦЕДУРИ ДОБОРУ СУДДІВ ДО ВИЩОГО АНТИКОРУПЦІЙНОГО СУДУ
}

Ключові слова: Вищчий антикорупщійний суд, Вищза кваліфікаџійна комісія суддів, Громадська рада міжнародних експертів, суддя, антикорупційні органи, спеціальна процедура добору суддів, доброчесність, кваліфікаційне оцінювання.

Ефективна протидія корупції неможлива без створення реальних механізмів, інститутів та органів, які б забезпечували системну боротьбу з цим негативним явищем. 18 жовтня 2006 р. в Україні була ратифікована Конвенція Організації Об'єднаних Націй проти корупції (далі - Конвенція). Приєднання України до міжнародної спільноти у цьому питанні мало на меті сприяння «затвердженню 
позитивного іміджу України як держави, де створюється сприятливий політичний клімат для широкомасштабної, взаємовигідної співпраці зі всіма країнами, зокрема в питаннях протидії корупції та іншим правопорушенням, які безпосередньо пов'язані з нею» [1].

В Індексі сприйняття корупції від Transparency International за 2016 р. Україна отримала 29 балів зі 100 можливих, що ставило нашу державу лише на 131 місце зі 176 країн, які потрапили до рейтингу [2]. А вже у 2018 р. Україна здобула 32 бали зі 100 можливих у дослідженні Transparency International «Індекс сприйняття корупції» (CPI) і посіла 120 місце (зі 180 країн) [3]. Серед умов, що сприяли покращенню показників індексу відзначили посилення діяльності Національного антикорупційного бюро України, зміни в організації роботи Національного агентства запобігання корупції з відмовою від колегіальності прийняття рішень, зміну керівництва Спеціалізованої антикорупційної прокуратури та затвердження нової процедури його призначення, формування Вищого антикорупційного суду, 3 повноваженнями, що відповідатимуть рекомендаціям Венеціанської комісії.

Передумовами для створення Вищого антикорупційного суду стали вимоги міжнародної світової спільноти та зобов’язання України перед Свропейським Союзом. Сьогодні суспільство покладає надії на покращення ситуації у сфері боротьби з корупцією.

Можна погодитися 3 думкою М. Костецького, що цей судовий орган має стати кінцевою ланкою у ланцюгу новостворених антикорупційних органів, яка зможе забезпечити невідворотність покарання для корупціонерів. Тільки невідворотність покарання та справедливі санкції за порушення кримінального законодавства матимуть реальний ефект на зниження рівня корупції в Україні. А також на реальне зменшення корумпованості державного сектора, що зі свого боку забезпечить зростання реального сектора економіки [4].

I. Ліщишин зазначає, що Вищий антикорупційний суд може стати фундаментом для активізації антикорупційної боротьби в державі [5]. Одна з основних позитивних переваг створення цього суду, на думку Б. Прокопіва, полягає в тому, що його функціонування «має значно пришвидшити строки розгляду корупційних справ» [6, с. 106].

Водночас процедура добору суддів до Вищого антикорупційного суду є недосконалою, що стало підставою для звернення до Касаційного адміністративного суду при Верховному Суді кандидатів у судді, які з різних причин залишили участь у конкурсі. До того ж на етапі формування законодавства про Вищий антикорупційний суд особливої актуальності для європейської держави набуває правозастосовчий аспект порядку добору суддів.

Дослідженню питань формування суддівського корпусу, утворення і функціонування антикорупційних судів, зокрема в зарубіжних країнах, присвячені пуб- 
лікації С. В. Глущенко, Л. С. Зуєвої, О. І. Пархоменко-Куцевіл, Б. В. Прокопіва, В. М. Трепак, К. В. Ростовської, Т. Г. Семків, І. В. Федорович та ін. Водночас сьогодні відсутній аналіз проблем формування Вищого антикорупційного суду в Україні. В сучасному світі складно уявити побудову та розвиток юридичних відносин без їхньої належної правової регламентації, тому існує необхідність теоретичних напрацювань для подальшого покращення правового забезпечення формування Вищого антикорупційного суду в нашій державі.

Наведене вище вказує на актуальність теми цієї статті.

Мета изього дослідження - обтрунтування пропозицій щзодо удосконалення процедури добору суддів до Вищцого антикорупизійного суду.

Немає сумніву в тому, що формування складу суду має відбуватися на рівних умовах щодо всіх суддів судів загальної юрисдикції, зокрема щодо суддів Вищого антикорупційного суду. Розглядаючи це питання, С. Желтухін наводить думку заступника голови Комітету Верховної Ради України з питань правової політики та правосуддя С. Алєксєєва, котрий вважає, що в Україні не варто створювати «елітні» суди та ставити одних суддів вище за інших. Не може один суд формуватися більш прозоро, а інший - навпаки. Формування будь-якого суду має здійснюватися на єдиних засадах: об'єктивності, неупередженості, прозорості. За його словами, не існує об'єктивного обгрунтування того, чому формування антикорупційного суду може якісно вирізнятися від формування інших судів [7].

При створенні будь-якого органу важливим є визначення засад його функціонування. Представник Антикорупційної ініціативи Свропейського Союзу Е. Ткешелашвілі зазначає, що «основним принципом створення антикорупційних судів має бути прозорий і ретельний процес добору суддів із залученням громадськості та представників міжнародних партнерів України» [8].

Вищий антикорупційний суд є судом з всеукраїнською юрисдикцією. Судді цього суду, як і інші судді судів загальної юрисдикції, призначаються на підставі результатів відкритого конкурсу.

Ч. 2 ст. 83 Закону України «Про судоустрій і статус суддів» встановлено, що критеріями кваліфікаційного оцінювання є: 1) компетентність (професійна, особиста, соціальна тощо); 2) професійна етика; 3 ) доброчесність [9].

Відповідно до ч. 4 ст. 8 Закону України «Про Вищий антикорупційний суд» від 07.06.2018 р. для сприяння Вищій кваліфікаційній комісії суддів України у встановленні кваліфікаційного оцінювання відповідності кандидатів на посади суддів Вищого антикорупційного суду критеріям доброчесності (моралі, чесності, непідкупності), а саме щодо законності джерел походження майна, відповідності рівня життя кандидата або членів його сім’ї задекларованим доходам, відповідності способу життя кандидата його статусу, наявності знань та практичних навичок для розгляду справ, віднесених до підсудності Вищого антикорупційного 
суду, утворюється Громадська рада міжнародних експертів (далі- ГРМЕ). ГРМЕ виконує свої повноваження у складі шести членів, які призначаються Вищою кваліфікаційною комісією суддів України виключно на підставі пропозицій міжнародних організацій (ст. 9) [10].

Громадська рада доброчесності, що утворена і здійснює діяльність відповідно до Закону України «Про судоустрій і статус суддів», на час діяльності ГРМЕ не залучається до встановлення відповідності кандидатів на посади суддів Вищого антикорупційного суду передбаченим законом критеріям для цілей кваліфікаційного оцінювання.

За ініціативою не менш ніж 3 членів ГРМЕ рішення щодо відповідності кандидата зазначеним критеріям підлягає розгляду на спеціальному спільному засіданні Вищої кваліфікаційної комісії суддів України (далі - ВККСУ) та ГРМЕ, і ухвалюється більшістю від їхнього спільного складу, за умови, що за нього проголосувало не менш ніж половина членів ГРМЕ. У разі неприйняття такого рішення кандидат вважається таким, що припинив участь у конкурсі. Голосування проводиться за відсутності кандидата, стосовно якого вирішується питання, та інших осіб, які не є членами ВККСУ та ГРМЕ. Таке спеціальне спільне засідання проводиться не пізніше, ніж на тридцятий день з дня оголошення результатів іспиту, що складається кандидатами для встановлення відповідності кандидата на посаду судді критерію професійної компетентності.

Ч. 9 ст. 9 Закону України «Про Вищий антикорупційний суд» визначено, що ГРМЕ: 1) збирає, перевіряє та аналізує інформацію щодо кандидатів на посади суддів Вищого антикорупційного суду; 2) надає ВККСУ інформацію щодо кандидатів на посади суддів Вищого антикорупційного суду; 3) бере участь у спеціальному спільному засіданні у передбачених цим Законом випадках; 4) вживає заходів щодо захисту персональних даних, інформації з обмеженим доступом, які стали відомі ГРМЕ, ïi членам з огляду на здійснення їхніх повноважень. Для здійснення повноважень, визначених цією статтею, членам ГРМЕ надається право безоплатного доступу до відкритих державних реєстрів (ч. 10 ст. 9). Крім цього, ГРМЕ складає висновок про невідповідність судді критеріям доброчесності та професійної етики.

Отже, відповідність кандидата на посаду судді Вищого антикорупційного суду критерію доброчесності є однією з обов'язкових умов для обіймання посади судді. Органом, який сприяє ВККСУ в оцінюванні відповідності кандидата такому критерію, є ГРМЕ.

Значна кількість адміністративних справ, що перебувала в провадженні Касаційного адміністративного суду у складі Верховного Суду, а також на розгляді Великої палати Верховного Суду, стосувалася припинення участі кандидатів у конкурсі на підставі їхньої невідповідності критерію доброчесності. Наприклад, 
в своєму рішенні № 9901/85/19 від 17 квітня 2019 р. Верховний Суд у складі колегії суддів Касаційного адміністративного суду зазначив, «що в умовах, коли законодавець не визначив критеріїв оцінювання, а особливо коли йдеться про оцінку таких загальних категорій, як-от «доброчесність» і «суспільна довіра», оцінювання завжди має суб’єктивний характер. За таких обставин вирішальним $\epsilon$ особисте переконання кожного члена спільного складу ВККС України та Громадської ради міжнародних експертів, яке зрештою і визначає характер їхнього голосування». Крім того, в рішенні суду зазначено, що «сама Громадська рада міжнародних експертів вийшла за межі наданих їй повноважень, оскільки керувалася необгрунтованими припущеннями» [11].

Отже, зазначене свідчить про те, що для правозастосовчої практики стосовно оскарження процедурних питань кваліфікаційного відбору має значення законодавча визначеність категорії «доброчесність» щодо кандидатів на посаду судді, а також законодавче закріплення «меж повноважень ГРМЕ».

Останнім часом приділяється увага різним аспектам доброчесності суддів. Наприклад, в ст. 62 Закону України «Про судоустрій і статус суддів» закріплений обов’язок судді щорічно подавати шляхом заповнення на офіційному вебсайті ВККСУ декларацію доброчесності за формою, що визначається Комісією. Декларація доброчесності судді складається з переліку тверджень, правдивість яких суддя повинен задекларувати шляхом їх підтвердження або непідтвердження.

Окрім цього, саме про суддівську доброчесність йдеться у звіті «Суддівська етика - принципи, цінності та якості» Генеральної Асамблеї Свропейської мережі рад юстиції у 2010 р. Суддя виконує обов'язки доброчесно, в інтересах правосуддя та суспільства. Він повинен поводитися доброчесно як у публічному, так i в приватному житті. 3 принципу доброчесності випливають два обов’язки: обов'язок бути непідкупним та обов'язок зберігати гідність та честь. Саме порядність та непідкупність визначаються як один із ключових аспектів. Порядність зобов'язує суддю утримуватися від будь-якої нетактовної або неделікатної поведінки, а не тільки від протиправної / протизаконної поведінки. Принципи дотримання етичних норм передбачені і в Бангалорських принципах поведінки суддів, які розміщені на сайті ВККС [12]. Вони дають базові принципи, на яких повинна будуватися судова система загалом, а також передбачають дотримання суддями етичних норм, акцентують увагу на «суспільну довіру» до діяльності судів.

Зрозуміло, що тільки після призначення на посаду судді можуть бути висунуті вимоги щодо етичності поведінки та відповідності вчинених ним дій певним моральним стандартам.

11 січня 2019 р. Громадська рада доброчесності затвердила індикатори визначення невідповідності суддів (кандидатів на посаду судді) критеріям доброчесності та професійної етики. Як зазначають розробники, документ розроблено 
на основі міжнародних практик у сфері суддівської доброчесності й етики, які зафіксовані у Бангалорських принципах поведінки суддів, коментарях до них, рекомендаціях Комітету Міністрів Ради Свропи, висновках Венеційської комісії та Консультативної ради європейських суддів, а також з урахуванням положень Кодексу суддівської етики, Керівних положень Громадської ради міжнародних експертів щодо проведення оцінки доброчесності, знань та практичних навичок кандидатів на посади суддів Вищого антикорупційного суду. Індикатори також засновані на попередній практиці Громадської ради доброчесності та враховують результати їхнього узгодження з ВККСУ. У змісті документа враховано думки експертів Ради Свропи, Свропейського Союзу та програми USAID «Нове правосуддя». Цей перелік індикаторів є орієнтовним. Перелік індикаторів планується доповнювати під час роботи Громадської ради доброчесності, і він буде спиратися на практику Громадської ради міжнародних експертів [13].

Це, безумовно, позитивний крок, але зазначені індикатори не розповсюджуються на процедуру добору суддів до Вищого антикорупційного суду і не визначають межі повноважень ГРМЕ.

Вбачається, що регламентовані критерії «доброчесності» мають бути диференційовані залежно від того, хто підлягає перевірці - суддя чи кандидат на посаду судді, який на момент перевірки не є суддею.

Нормативне відтворення критерію «доброчесність» у розрізі його конкретних ознак з урахуванням Бангалорських принципів сприятиме конкретному суб'єктивному розумінню особи, що подає документи на конкурс, відповідності їі вимогам закону та унеможливить зловживання з боку ГРМЕ та ВККСУ внаслідок особистих антипатій та міжособистісного конфлікту між претендентом та членом ГРМЕ або ВККСУ. Крім того, це дасть змогу зазначену категорію зробити не виключно моральною конструкцією, що має зовнішній характер та оцінюється за зовнішніми абстрактними критеріями, і надасть можливість однотипного застосування.

Другим актуальним питанням, яке стосується процедури добору суддів до Вищого антикорупційного суду, є дотримання принципу прозорості. Зокрема про недосконалість процедури проведення спеціального спільного засідання свідчать непоодинокі випадки звернення до Касаційного адміністративного суду при Верховному Суді кандидатів на посаду судді, які оскаржували рішення ВККСУ стосовно непрозорості цієї процедури. Колегія суддів Касаційного адміністративного суду при Верховному Суді своїм рішенням у справі № П/9901/246/19 від 11 липня 2019 р. визнала протиправність дій ВККСУ щодо ненадання інформації на запит 46 кандидатів на посаду судді стосовно кількості голосів «за» та кількості голосів «проти» членів ВККСУ та окремо кількості голосів «за» та кількості голосів «проти» членів ГРМЕ щодо рішення про відповідність кандидатів на поса- 
ди суддів Вищого антикорупційного суду критеріям, передбаченим ч. 4 ст. 8 Закону України «Про Вищий антикорупційний суд». Суд зазначив, що ненадання інформації про кількість голосів суперечить Закону України «Про доступ до публічної інформації» [14].

Згідно з ч. 1 ст. 1 Закону України «Про доступ до публічної інформації» публічна інформація - це відбита та задокументована будь-якими засобами та на будь-яких носіях інформація, що була отримана або створена в процесі виконання суб'єктами владних повноважень своїх обов'язків, передбачених чинним законодавством, або яка знаходиться у володінні суб'єктів владних повноважень, інших розпорядників публічної інформації [15].

Із цього визначення випливає, що публічною інформацією $є$ та, що відбита або задокументована будь-якими засобами та на будь-яких носіях. Інформація, яку запитували кандидати на посаду судді, задокументована у відповідних рішеннях ВККСУ.

Відповідно до ст. 19 зазначеного Закону запит на інформацію - це прохання особи до розпорядника інформації надати публічну інформацію, що знаходиться у його володінні. Також у цьому Законі закріплено обов'язок розпорядника інформації мотивувати підставу для своєї відмови у наданні публічної інформації (п. 4 ст. 22).

Як обгрунтування неможливості надання запитуваної інформації ВККСУ навела те, що, згідно з пп. 4.11.10.2 п. 4.11 розділу IV Регламенту ВККСУ, члени ВККСУ, ГРМЕ та особи, які забезпечують переклад, не мають права розголошувати будь-яку інформацію щодо обговорення та голосування [16].

Аналіз ст. 6 Закону України «Про доступ до публічної інформації» свідчить про те, що запитувана інформація стосовно кількості голосів «за» і «проти» не підпадає під критерії інформації з обмеженим доступом.

Відповідно до Регламенту ВККСУ не підлягає розголошенню саме інформація щодо обговорення та голосування, а інформація щодо кількості голосів «за» та «проти» членів ВККСУ та ГРМЕ під час вирішення питання стосовно відповідності певних кандидатів на посаду суддів Вищого антикорупційного суду критеріям, визначеним ч. 4 ст. 8 Закону України «Про Вищий антикорупційний суд», належить до знеособленої інформації та не стосується персональних результатів голосування членів ВККСУ та ГРМЕ з цього питання, а тому не може охоплюватися забороною, встановленою пп. 4.11.10.2 п. 4.11 розділу IV Регламенту ВККСУ.

Отже, право особи на отримання знеособленої інформації стосовно проведення кваліфікаційного оцінювання охоплює право на доступ до публічної інформації шляхом надання ВККСУ (розпорядником інформації) достовірної інформації на запит особи. Вбачається, що ненадання інформації на запит або надання 
інформації, яка не відповідає критеріям достовірності, можна вважати порушенням принципу прозорості під час формування Вищого антикорупційного суду.

На підставі викладеного вище для забезпечення реалізаиії принципу прозорості в процедурі добору суддів до Вищого антикорупиійного суду можна запропонувати:

1) визначити в Законі Украӥни «Про судоустрій і статус суддів» критерії категорії «доброчесність» для кандидатів на посаду суддi, з урахуванням того, щзо критерій «доброчесність» застосовується для всіх кандидатів на посади судді судів загальної юрисдикиії;

2) встановити в Законі України «Про Вищчий антикорупційний суд» обов'язок Вищої кваліфікачійної комісії суддів України офіційно оприлюднювати знеособлену інформацію щодо результатів голосування на спеціальному спільному засіданні ВККСУ і ГРМЕ із дотриманням вимог конфіденційності персонального голосування.

Дотримання принщипів об’'єктивності, прозорості, ретельності під час проведення прочедури спеціального спільного засідання ВККСУ і ГРМЕ допоможе забезпечити уникнення обтрунтованих сумнівів щодо доброчесності та практичних навичок кандидата на посаду судді Вищого антикорупиійного суду.

Проведений аналіз не вичерпує всіх проблемних аспектів організації діяльності Вищого антикорупційного суду, і відповідні питання мають стати предметом подальших наукових досліджень.

1. Матеріали пленарного засідання Верховної Ради України від 18 жовтня 2006 р. Oфiиійний портал Верховної Ради України. URL: http://iportal.rada.gov.ua/print/8004.html (дата звернення: 01.10.2019 р.).

2. Індекс сприйняття корупції CPI-2016. URL: https://ti-ukraine.org/research/indeks-koruptsiyi-cpi-2016/ (дата звернення: 10.10.2019 р.).

3. Індекс сприйняття корупції CPI-2018. URL: https://ti-ukraine.org/research/indeks-spryjnyattya-koruptsiyi-2018/ (дата звернення: 10.10.2019 р.).

4. Костецький М. Чому важливі антикорупційні суди. URL: https://nv.ua/ukr/biz/experts/ chomu-vazhlivi-antikorupciyni-sudi-2008723.html (дата звернення: 15.10.2019 p.).

5. Ліщишин I. Щодо необхідності створення Вищого антикорупційного суду. URL: http:// yur-gazeta.com/publications/practice/sudova-praktika/shchodo-neobhidnosti-stvorennya-vishchogoantikorupciynogo-sudu.html (дата звернення: 15.10.2019р.).

6. Прокопів Б. Специфіка функціонування Вищого антикорупційного суду в Україні: міжнародний досвід та українські реалії. Актуальні проблеми правознавства. 2018. Вип. 3(15). C. $103-107$.

7. Желтухін Є. Особливий антикорупційний: монополізація правосуддя? Юридична Газета. URL: http://alekseev.com.ua/wp-content/uploads/2017/02 (дата звернення: 25.10.2019 р.).

8. Довга дорога до антикорупційних судів. URL: http://nv.ua/ukr/opinion/tkeshelashvili/ dovga-doroga-do-antikoruptsijnih-sudiv1323280.html (дата звернення: 10.10.2019р.).

9. Про судоустрій і статус суддів: Закон України від 2 червня 2016 р. Відомості Верховної Ради України. 2016. № 31. Ст. 545. (Із змінами). 
10. Про Вищий антикорупційний суд: Закон України від 7 червня 2018 р. Відомості Верховної Ради Украӥни. 2018. № 24. Ст. 212.

11. Рішення Касаційного адміністративного суду у складі Верховного Суду від 17 квітня 2019 p. у справі №9901/85/19. Сдиний державний реєстр судових рімень. URL: http://reyestr.court.gov.ua/Review/81366535 (дата звернення: 01.10.2019 p.).

12. Бангалорські принципи поведінки суддів від 19 травня 2006 р.: Схвалено Резолюцією Економічної та Соціальної Ради ООН 27 липня 2006 р. № 2006/23. Офіиійний веб-портал Верховної Ради Украӥни. URL: http://zakon2.rada.gov.ua/laws/show/995_j67 (дата звернення: 10.10.2019р.).

13. Стали відомі індикатори визначення невідповідності суддів критеріям доброчесності. Судебно-юридическая газета. URL: https://sud.ua/ru/news/sud-info/132839-stali-vidomi-indikatoriviznachennya-nevidpovidnosti-suddiv-kriteriyam-dobrochesnosti (дата звернення: 01.11.2019р.).

14. Рішення Касаційного адміністративного суду у складі Верховного Суду від 11 липня 2019 p. у справі №П/9901/246/19. Соиний державний реєстр судових рімень. URL: http://reyestr.court.gov.ua/Review/83070061

15. Про доступ до публічної інформації: Закон України від 13 січня 2011 р. № 2939-VI. Відомості Верховної Ради України. 2011. № 32. Ст. 314. (Із змінами).

16. Регламент Вищої кваліфікаційної комісії суддів України від 13 жовтня 2016 р. № 81/зП-16 (зі змін.). URL: https://vkksu.gov.ua/ua/about/reglament-vkks-ukraini/ (дата звернення: 10.10 .2019 р.).

DOI 10.31558/2518-7953.2019.2.7

УДК 342.32

I. B. Idecic,
асистент кафедри міжнародного
та європейського права
Національного університету
«Одеська юридична академія»,
кандидат юридичних наук

\section{СТАТУТИ ТЕРИТОРІАЛЬНИХ ГРОМАД МІСТ: ДОСВІД ЗАСТОСУВАННЯ В УКРАЇНІ ЄВРОПЕЙСЬКИХ МУНІЦИПАЛЬНИХ СТАНДАРТІВ}

Ключові слова: статут територіальної громади, територіальна громада, місцеве самоврядування, муніщципальне управління, хартія, європейські муніципальні стандарти.

Президент України підкреслив, що у його діяльності чільне місце посідатиме проведення чергового етапу муніципальної реформи в Україні, спрямованого на іiї остаточне завершення. Ця реформа триває від часу проголошення незалежності України, а тому потребує якнайшвидшого логічного завершення. Відповідно, актуальними $є$ наукові розробки у цьому напрямі, які сприятимуть як пошуку нових ідей для завершення реформи, так і підвищенню ефективності правотворчості у відповідній сфері. 